\title{
Opportunistic screening for osteoporosis correlating the bone densities of jaws with multislice computed tomography for cervical vertebrae
}

\author{
- Mayara de Cassia Cunha Cheade Department of Stomatology, Public Oral Health and Forensic Dentistry, School \\ of Dentistry, University of São Paulo, Ribeirão Preto, Brazil • Luciana Munhoz Department of Stomatology, School of \\ Dentistry, University of São Paulo, São Paulo, SP, Brazil • Emiko Saito Arita Department of Stomatology, School of \\ Dentistry, University of São Paulo, São Paulo, SP, Brazil • Plauto C Aranha Watanabe Department of Stomatology, \\ Public Oral Health and Forensic Dentistry, School of Dentistry, University of São Paulo, Ribeirão Preto, Brazil
}

\begin{abstract}
Objectives: to evaluate the correlation of the bone mineral density (BMD) from maxilla and mandible with that of the cervical vertebrae, using Hounsfield units (HU) and multislice computed tomography (CT) to verify whether CT could be a useful osteoporosis screening tool. Methods: 79 multislice CT examinations from patients who underwent CT examinations of maxilla, mandible and cervical vertebrae simultaneously were included. The following left and right anatomical regions were assessed: mandible ramus; mandible head; the area below the inferior first molar and the area below the upper cuspids. HU were measured in each area using a 0.1 $\mathrm{cm}$ region of interest (ROI) positioned in the center of the slice. Results: a significant correlation between the cervical spine and the posterior region of the mandible was found, as well as a significant correlation between the anterior maxilla and the cervical spine. However, no correlation was found between the cervical spine and other parts of the mandible, such as ramus and head of mandible. Conclusions: As anterior maxillary bone and posterior mandible bone HU values correlate with cervical bone HU values, this examination may be applied as osteoporosis screening tool.
\end{abstract}

DESCRIPTORS | Osteoporosis; Computed tomography; Hounsfield Unit; Bone Mineral Density.

RESUMO | Utilização exames de tomografia computadorizada da maxila e mandíbula e sua correlação com as vértebras cervicais objetivando o rastreamento de pacientes com risco de osteoporose - Objetivos: avaliar a correlação da densidade mineral óssea (DMO) da maxila e mandíbula com as vértebras cervicais, utilizando unidades de Hounsfield (HU), utilizando tomografia computadorizada (TC) multislice, para verificar se a TC pode ser útil como ferramenta de rastreamento da osteoporose. Métodos: 79 exames de tomografia computadorizada multislice de pacientes que foram submetidos a CTs de maxila, mandíbula e vértebras cervicais simultaneamente foram incluídos. As seguintes regiões anatômicas esquerda e direita foram avaliadas: ramo da mandíbula; cabeça mandibular; a área abaixo do primeiro molar inferior e a área abaixo das cúspides superiores. HU foram medidos em cada área usando uma região de interesse (ROI) de $0.1 \mathrm{~cm}$ posicionada no centro do corte tomográfico. Resultados: Foi encontrada uma correlação significativa entre a coluna cervical e a região posterior da mandíbula, bem como uma correlação significativa entre a região anterior da maxila e a coluna cervical. No entanto, nenhuma correlação foi encontrada entre a coluna cervical e outros locais da mandíbula, como o ramo mandibular e a cabeça. Conclusões: Como os valores de HU do osso anterior e posterior da mandíbula se correlacionam com os valores de HU do osso cervical, este exame pode ser aplicado a ferramentas de rastreio da osteoporose.

DESCRITORES | Osteoporose; Tomografia Computadorizada; Unidade de Hounsfield; Densidade Mineral Óssea.

CORRESPONDING AUTHOR | • Luciana Munhoz Department of Stomatology, School of Dentistry, University of São Paulo • Av. Lineu Prestes, 2227 São Paulo, SP, Brazil • 05508 000 E-mail: dra.lucimunhoz@usp.br

- Received Feb 27,2019 • Accepted Apr 2, 2019

- Dol http://dx.doi.org/10.11606/issn.2357-8041.clrd.2019.155263 


\section{INTRODUCTION}

Along with the worldwide phenomenon of increase in elderly population, osteoporosis has becoming a major public health concern. ${ }^{1}$ Osteoporosis is typically characterized by an age-related reduction in bone strength, which predisposes the individuals affected to low-energy fractures. Osteoporosis is a common disease with enormous implications for the individuals affected and society as a whole. Information regarding bone mineral density obtained opportunistically from computed tomography (CT) performed with different imaging objectives may provide useful data to screen patients at osteoporosis risk. ${ }^{2}$

Early diagnosis of osteoporosis is essential. However, the silent nature of osteoporosis delays diagnosis. ${ }^{3}$ In Dentistry, its early detection is important because patients with osteoporosis may suffer from higher failure rates of dental implant placement ${ }^{4}$ and complications with other dental procedures wose results are associated with bone healing or remodelation.

Dual X-ray absorptiometry (DXA) is currently the standard for assessing osteopenia, osteoporosis or bone mineral density (BMD) and has been highly correlated with fracture risk and treatment efficacy. ${ }^{5}$ The use of Hounsfield unit (HU) from CT scanning to assess BMD of the vertebrae has recently been described, and several subsequent studies exploring its utility in assessing fracture risk and prognostic success. ${ }^{6,7}$

The use of Hounsfield units (HU) from CT scanning to assess regional BMD of the column has recently been studied and the correlations between $\mathrm{HU}$ and BMD have been established, ${ }^{6}$ mainly because they are directly related to tissue attenuation coefficients. The information provided by a simple HU measurement can be valuable to detection of patients who need DXA examination referral. ${ }^{8}$

In Dentistry, many researchers advocate that dental radiographs are useful to osteoporosis screening ${ }^{2,9,10}$ as morphologic alterations in jaws are observed. ${ }^{11}$ Considering CT, the correlation between the BMD of the cervical vertebrae and the lumbar vertebrae, also between the BMD of the cervical vertebra and mandible, has already been stablished. ${ }^{12}$ Also, the correlation between BMD and HU using tomographic images may be a method for diagnosing patients with mineral bone disease and assessing risk factors for fracture. ${ }^{7,13}$

Thus, this investigation aimed to evaluate the correlation of BMD from maxilla and mandible with the cervical vertebrae, using $\mathrm{HU}$ from $\mathrm{CT}$ examinations to verify whether CT scans from maxilla and mandible could be useful as an osteoporosis screening tool.

\section{METHODS AND MATERIALS}

This research has the approval of the Research Ethics Committee of FOUSP (School of Dentistry of São Paulo, Ribeirão Preto), under the No. 544.527; CAAE: 25099614.2.0000.0075. The guidelines of Helsinki were followed in this investigation.

The CT examinations were performed in a private Radiology clinic, which performs approximately one thousand head and neck CTs each year for medical and dentistry purposes. Head and neck CT examinations performed from 20122013 were fully assessed. A convenience sample of 79 multislice CT examinations (35 males and 44 females) from patients who underwent maxilla, mandible and cervical vertebrae ( $\mathrm{C} 1, \mathrm{C} 2$ and $\mathrm{C}_{3}$ ) scans simultaneously were included in this study. CT examinations whose maxilla, mandible and cervical vertebrae ( $\mathrm{C}_{1}, \mathrm{C}_{2}$ and $\left.\mathrm{C}_{3}\right)$ were not scanned simultaneously and examinations with any technical failure or artifacts that would not allow the correct measurement of the HU in the anatomical area selected were excluded from this study.

Patients filled out a form with personal characteristics, lifestyle habits, and medical 
history. Patients with diabetes, thyroid disorders, osteometabolic diseases (other than osteopenia and osteoporosis), alcohol, and tobacco chronic use were excluded. None of participants had suffered any previous fracture in either the lumbar vertebrae or the femoral neck.

The images were obtained in helical multislice CT scanner equipment (Somatom Volume Zoom Siemens-brand, 16 channels - Erlangen, Germany) using $1.0 \mathrm{~mm}$ slices (time image reconstruction 16 images/s, 50KW). Patients were positioned in dorsal decubitus, and their heads were carefully positioned using the nasal/tragus line as a reference to be parallel to the equipment's Gantry. A scout image was performed to every patient to verify the correct positioning. All the scans were executed from the Glabella region to the hyoid bone to evaluate the entire maxilla, mandible and cervical vertebrae. Digital Imaging and communications in Medicine (DICOM) format images were assessed using E-film (eFilm, version 1.5.3, Merge Healthcare, Milwaukee, WI).
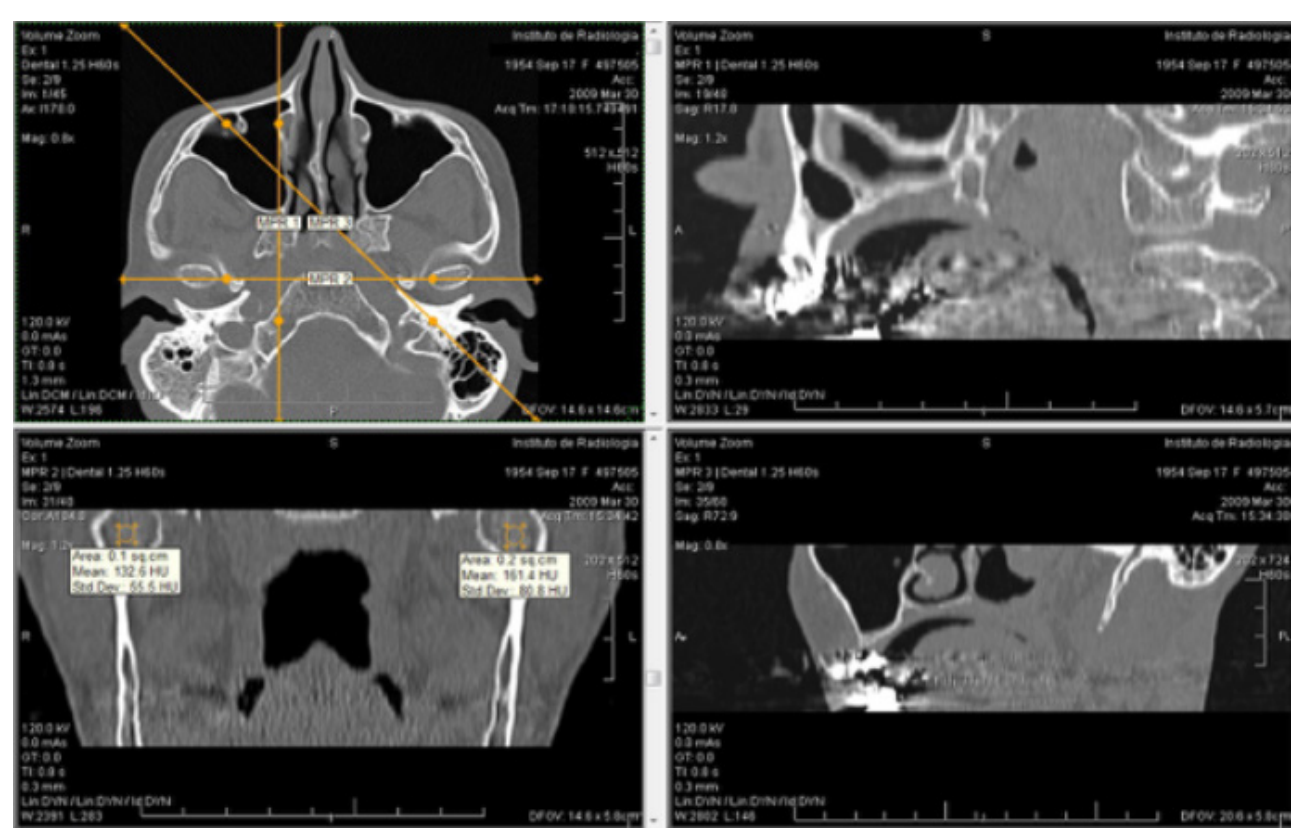

Figure 1 | Example of mandible head HU measurement using coronal slices. Axial and sagittal slices were used to guide the positioning of the ROIs in the correct anatomical area.

\section{Analysis of the CT scans}

For each patient selected, the following left and right regions of CT scans were assessed: mandible ramus; mandible head; the area below the inferior first molar and the area below the upper cuspids using coronal slices except for the area below upper cuspids. Vertebrae $\mathrm{C} 1, \mathrm{C} 2$ and $\mathrm{C}_{3}$ were analyzed using sagittal slices. HU were measured in each region selected using a $0.1 \mathrm{~cm}$ region of interest (ROI) positioned in the center of the slice. Angulations of the slices selected were adjusted manually to reduce the differences in head position among patient sample. Axial sections were used to guide the ROI placement in the correct anatomical area. In Figure 1, an example of the HU measurements methodology is provided.

One examiner, ${ }^{14,15}$ a $\mathrm{PhD}$ candidate in Oral Radiology with 8 years of experience, carried out the aforementioned analysis of CT scans. This analysis was repeated for a randomly selected subsample of 8 CT images (about 10\% of the overall study sample) to establish intra-examiner agreement. For each ROI, the examiner repeated the evaluations three times in three different weeks to avoid memory bias. 


\section{Statistical analyses}

All analyses were performed in the MedCalc program (Ostend, Belgium). Correlations were analyzed using the Pearson correlation test, considering significant if $\mathrm{p}<0.05$. The correlation tests were performed arranging $\mathrm{C}_{1}, \mathrm{C}_{2}$, and $\mathrm{C}_{3} \mathrm{HU}$ values in a single group, as well as $\mathrm{HU}$ values of right and left size of the anatomical regions evaluated.

\section{RESULTS}

The data are shown as mean and standard deviation. The mean age of the patients studied was 58 years old (40 to 84 years old).
Mean HU of each region analyzed is demonstrated in Table 1, as well as the maximum and minimum HU value obtained.

The bone densities of the cervical spine $(\mathrm{C} 1$, $\mathrm{C}_{2}$, and $\mathrm{C}_{3}$ ) were significantly correlated with the anterior maxilla measurements $(\mathrm{r}=0.27 ; \mathrm{p}=0.01)$ and the posterior region of the mandible $(\mathrm{r}=0.25 ; \mathrm{p}$ $=0.02$ ). No correlation was found between mandible head and cervical spine ( $\mathrm{r}=0.20 ; \mathrm{p}=0.06)$, as well as mandible ramus and cervical spine $(\mathrm{r}=0.14 ; \mathrm{p}=$ o.21). The results of correlation tests are shown in Table 2.

Table 1 | Mean, maximum and minimum Hounsfield values obtained in each region assessed (C1, C2, C3, mandible ramus and mandible head, area below the inferior first molar, area above the cuspid).

\begin{tabular}{|c|c|c|c|c|c|c|c|c|c|c|c|}
\hline & $\mathrm{C} 1$ & $\mathrm{C} 2$ & $\mathrm{C} 3$ & Ramus $\mathrm{R}$ & Ramus L & Head R & Head L & $\begin{array}{l}\text { Inferior } \\
\text { molar R }\end{array}$ & $\begin{array}{l}\text { Inferior } \\
\text { molar L }\end{array}$ & $\begin{array}{c}\text { Upper } \\
\text { cuspid R }\end{array}$ & $\begin{array}{c}\text { Upper } \\
\text { cuspid L }\end{array}$ \\
\hline Mean & 222 & 258 & 394 & 102 & 91 & 292 & 303 & 182 & 173 & 378 & 349 \\
\hline SD & 143 & 159 & 174 & 221 & 210 & 136 & 135 & 181 & 175 & 223 & 252 \\
\hline CV (\%) & 64 & 61 & 44 & 216 & 230 & 46 & 44 & 99 & 101 & 58 & 72 \\
\hline Min & -48 & -16 & 18 & -323 & -254 & -26 & -2 & -128 & -99 & -9 & -134 \\
\hline Max & 591 & 703 & 994 & 1018 & 809 & 755 & 695 & 624 & 755 & 921 & 1092 \\
\hline
\end{tabular}

Abbreviations: SD: Standard deviation; CV: Coefficient of variation; R: right; L: left.

Table 2 | Correlation between Hounsfield units of the cervical spine (C1, C2, and C3 vertebrae) with different maxillofacial regions.

\begin{tabular}{l|c|c|}
\hline Region evaluated & $r$ & $p$ value \\
\hline Anterior maxilla & 0.27 & 0.01 \\
\hline Posterior mandible & 0.25 & 0.02 \\
\hline Mandible head & 0.20 & 0.06 \\
\hline Mandible ramus & 0.14 & 0.21 \\
\hline
\end{tabular}

r: Pearson correlation coefficient. Significant when $p$ value $<0.05$.

\section{DISCUSSION}

The dental practitioner should be able to screen systemic diseases that can also affect oral cavity, such as osteoporosis. By recognizing the disease risk and referring the patient to proper treatment in early phases, the dentist may improve patient's quality of life and reduce the risk of tooth loss, ${ }^{2,16}$ as well as assist society in controling the financial burden associated with osteoporosis.
Currently, the most accepted method for measuring BMD is DXA. ${ }^{3}$ However, DXA is not widely available in many countries; thus, many screening techniques using other imaging examinations have been studied. The use of CT scans of mandible and maxilla could be an useful osteoporosis screening tool. Previously, using cone beam computed tomography (CBCT), one found the radiodensity of cervical vertebrae (particularly $\mathrm{C} 1$ and C2) correlates strongly with DXA T-scores values obtained from lumbar spine; accordingly, the cervical radiodensity obtained from CBCT could be beneficial to predict osteoporosis status. ${ }^{17}$

$\mathrm{HU}$ values obtained from multislice CT examinations had also correlated with DXA previously. ${ }^{6,13}$ Strong correlation between the HU values from the lumbar spine and BMD had already been observed. ${ }^{18}$ Additionally, T-scores from 
femur has also been associated with HU values from cervical vertebrae ${ }^{19}$, and HU from maxillary and mandibular sites were lower in patients with osteopenia or osteoporosis. ${ }^{8}$ Mean maxillary HU values in distinct sites reported in literature by Woon et al, ${ }^{8}$ which indicates a difference in $\mathrm{HU}$ values between patients with low BMD and normal patients, confirmed by BMD, were similar to the mean $\mathrm{HU}$ values obtained in this investigation, particularly in the mandible ramus of osteoporotic patients (227.01+195.22). This may indicate that the patients assessed in this study should be evaluated individually to be referred to DXA.

Similarly to bone in other parts of the spine, the cervical spine is affected by physiological processes such as aging and degeneration. As one get older, cervical spine BMD decreases., ${ }^{20,21}$ Maxillofacial area, specially mandible, is proven to be affected by the systemic BMD decrease..$^{22,23}$

In this study, a significant correlation was found between the cervical spine and the posterior region of the mandible, as well as a significant correlation between the anterior maxilla and the cervical spine. However, no correlation was found between the cervical spine and other parts of the mandible, such as mandible ramus and mandible head. This may suggest the bone nearby alveolar bone or the alveolar bone itself could have higher remodeling rates than the bone in the mandible ramus or mandible head.

\section{CONCLUSIONS}

Within the limitations of this study, the conclusion was that anterior maxillary bone and posterior mandible bone $\mathrm{HU}$ values correlate with cervical bone $\mathrm{HU}$ values, which may indicate that HU values obtained in maxillary or mandibular CT obtained for other examinations purposes could help in screening patients with osteoporosis, providing proper referring for these patients. Further most comprehensive prospective studies should be performed to evaluate this opportunistic imaging tool further.

\section{REFERENCES}

1. Unnanuntana A, Gladnick BP, Donnelly E, Lane JM. The assessment of fracture risk. J Bone Joint Surg Am. 2010 Mar;92(3):743-53. doi: 10.2106/JBJS.I.oo919.

2. White SC. Oral radiographic predictors of osteoporosis. Dentomaxillofac Radiol. 2002 Mar;31(2):84-92. doi: 10.1038/ sj.dmfr.4600674.

3. 3. Guglielmi G. Preface: imaging of osteoporosis. Radiol Clin North Am. 2010 May; 48(3):xv. doi: 10.1016/j. rcl.2010.03.002.

4. Giro G, Chambrone L, Goldstein A, Rodrigues JA, Zenóbio E, Feres M, et al. Impact of osteoporosis in dental implants: a systematic review. World J Orthop. 2015 Mar;6(2):311-5. doi: 10.5312/wjo.v6.i2.311.

5. Lewiecki EM, Borges JL. Bone density testing in clinical practice. Arq Bras Endocrinol Metabol. 2006 Aug;50(4):586-95 doi: 10.1590/Sooo4-27302006000400004.

6. Lee S, Chung CK, Oh SH, Park SB. Correlation between bone mineral density measured by dual-energy x-ray absorptiometry and hounsfield units measured by diagnostic CT in lumbar spine. J Korean Neurosurg Soc. 2013 Nov;54(5):3849. doi: 10.3340/jkns.2013.54.5.384.

7. Kim YS, Lee S, Sung YK, Lee BG. Assessment of osteoporosis using pelvic diagnostic computed tomography. J Bone Miner Metab. 2016 Jul;34(4):457-63. doi: 10.1007/soo774015-0684-0.

8. On SW, Kim HJ, Kim J, Choi JW, Jung YW, Song SI. Effect of osteoporosis on bone density of orthognathic osteotomy sites in maxillofacial region. J Craniofac Surg. 2016 Oct;27(7):e678-e83. doi: 10.1097/SCS.0000000000003064.

9. Munhoz L, Cortes ARG, Arita ES. Assessment of osteoporotic alterations in type 2 diabetes: a retrospective study. Dentomaxillofac Radiol. 2017 Aug;46(6):20160414. doi: 10.1259/ dmfr.20160414.

10. Calciolari E, Donos N, Park JC, Petrie A, Mardas N. Panoramic measures for oral bone mass in detecting osteoporosis: a systematic review and meta-analysis. J Dent Res. 2015 Mar;94(3 Suppl):17S-27S. doi: 10.1177/0022034514554949.

11. White SC, Atchison KA, Gornbein JA, Nattiv A, Paganini-Hill A, Service SK, Yoon DC. Change in mandibular trabecular pattern and hip fracture rate in elderly women. Dentomaxillofac Radiol. 2005 May;34(3):168-74. doi: 10.1259/ $\mathrm{dmfr} / 32120028$.

12. Naitoh M, Kurosu Y, Inagaki K, Katsumata A, Noguchi T, Ariji E. Assessment of mandibular buccal and lingual cor- 
tical bones in postmenopausal women. Oral Surg Oral Med Oral Pathol Oral Radiol Endod. 2007 Oct;104(4):545-50. doi: 10.1016/j.tripleo.2007.04.034.

13. Al-Bahrani Z. Validity of Hounsfield Units from computed tomographic images of mandibular bone in detection of osteoporosis. JBCD. 2014;26(3):79-83.

14. Ragghianti Zangrando MS, Chambrone D, Pasin IM, Conde MC, Pannuti CM, de Lima LA. Two-year randomized clinical trial of enamel matrix derivative treated infrabony defects: radiographic analysis. BMC Oral Health. 2014 Dec;14:149. doi: 10.1186/1472-6831-14-149.

15. Lee B, Park Y, Ahn J, Chun J, Park S, Kim M, et al. Assessment of the proximity between the mandibular third molar and inferior alveolar canal using preoperative $3 \mathrm{D}-\mathrm{CT}$ to prevent inferior alveolar nerve damage. Maxillofac Plast Reconstr Surg. 2015 Sep;37(1):30. doi: 10.1186/s40902-015-0030-4.

16. Hildebolt CF. Osteoporosis and oral bone loss. Dentomaxillofac Radiol. 1997 Jan;26(1):3-15. doi: 10.1038/sj.dmfr. 4600226 .

17. Barngkgei I, Joury E, Jawad A. An innovative approach in osteoporosis opportunistic screening by the dental practitioner: the use of cervical vertebrae and cone beam computed tomography with its viewer program. Oral Surg Oral Med Oral Pathol Oral Radiol. 2015 Nov;120(5):651-9. doi: 10.1016/j.0ooo.2015.08.008.
18. Lee IJ, Lee JJ, Bae JH, Hwang E, Lee S, Cho M, et al. Significance of osteoporosis in facial bone density using computed tomography. J Craniofac Surg. 2013 Mar;24(2):428-31. doi: 10.1097/SCS.obo13e3182801333.

19. Schreiber JJ, Anderson PA, Rosas HG, Buchholz AL, Au AG. Hounsfield units for assessing bone mineral density and strength: a tool for osteoporosis management. J Bone Joint Surg Am. 2011 Jun;93(11):1057-63. doi: 0.2106/JBJS.J.o0160.

20. Tay WL, Chui CK, Ong SH, Ng AC. Osteoporosis screening using areal bone mineral density estimation from diagnostic CT images. Acad Radiol. 2012 Oct;19(10):1273-82. doi: 10.1016/j.acra.2012.05.017.

21. Adams JE. Advances in bone imaging for osteoporosis. Nat Rev Endocrinol. 2013 Jan;9(1):28-42. doi: 10.1038/nrendo.2012.217.

22. Munhoz L, Aoki EM, Cortes ARG, de Freitas CF, Arita ES. Osteoporotic alterations in a group of different ethnicity Brazilian postmenopausal women: an observational study. Gerodontology. 2018 Jun;35(2):101-9. doi: 10.1111/ger.12322.

23. Jonasson G, Jonasson L, Kiliaridis S. Changes in the radiographic characteristics of the mandibular alveolar process in dentate women with varying bone mineral density: a 5-year prospective study. Bone. 2006 May;38(5):714-21. doi: 10.1016/j.bone.2005.10.008. 